DOI: $10.18276 /$ sip.2016.44/3-18

\title{
Żaneta Tatara*
}

Akademia Leona Koźmińskiego

\section{ZATRUDNIENIE W OCHRONIE ZDROWIA W POLSCE NA TLE MIGRACJI I POZIOMU WYNAGRODZEŃ LEKARZY}

\begin{abstract}
Streszczenie
W niniejszym artykule podjęto próbę przedstawienia rynku pracy w obszarze ochrony zdrowia ze szczególnym uwzględnieniem wpływu wynagrodzenia i migracji zarobkowej na jego kondycję. Według Światowej Organizacji Zdrowia (WHO) migracja kadr medycznych może doprowadzić do nierównego dostępu do opieki nie tylko na terenie danego kraju, lecz również w skali globalnej. Analiza przypadku dotyczy rynku pracy jednej z grup pracowników ochrony zdrowia - lekarzy na terenie Polski. Materiał został przygotowany na podstawie analiz i raportów Głównego Urzędu Statystycznego (GUS), Eurostatu, Organizacji Współpracy Gospodarczej i Rozwoju (OECD), Światowej Organizacji Zdrowia (WHO), Naczelnej Izby Lekarskie (NIL), Ministerstwa Zdrowia, a także Centrum Systemów Informacyjnych Ochrony Zdrowia (CSIOZ).
\end{abstract}

Słowa kluczowe: ochrona zdrowia, zatrudnienie lekarzy, migracja zarobkowa, wynagrodzenia

\section{Wprowadzenie}

Zgodnie ze słowami Schopenhauera, że „choć zdrowie nie jest na pewno wszystkim, to bez zdrowia wszystko jest niczym”, dla sprawnie działającej gospo-

\footnotetext{
*Adres e-mail: zaneta.tatara@gmail.com.
} 
darki kadra medyczna jest kapitałem. Na temat zdrowia i jego wpływu na gospodarkę rozprawiał już Arystoteles, a ewolucja powyższej koncepcji stanowiła pryncypium do prowadzenia badań ekonomicznych w kierunku określenia wpływu zdrowia społeczeństwa na wzrost gospodarczy kraju (Suchecka, 2010, s. 14). „Wśród ekonomistów najwięcej dyskusji wywołuje powszechnie obserwowana w sektorze zdrowia niewłaściwa alokacja pieniężnych środków publicznych. (...) Koniczność racjonalnego gospodarowania związana jest z ograniczonością zasobów, do których zalicza się zasoby ludzkie (wraz z wiedzą i praktycznymi umiejętnościami” (Suchecka, 2010, s. 15).

Popyt na zdrowie determinuje podaż pracy. $Z$ punktu widzenia świadczeniobiorcy jest nią usługa - wizyta u lekarza. Podaż pracy powinno się określać jako aktywność zawodową (liczbę oferowanych roboczogodzin) lub po skorygowaniu o efektywność pracy - faktyczną liczbę świadczonych usług. Wyżej wymienione wskaźniki mogą zupełnie inaczej reagować na zmianę jednostkowej stawki płacy (funkcja podaży). Fundamentalne przyczyny wzrostu ceny pracy lekarza związane są w takich krajach jak Polska z międzynarodowym charakterem współczesnych rynków zdrowia. Zgodnie z teorią Heckschera-Ohlina ceny czynników wytwórczych na rynkach międzynarodowych mają tendencję do wyrównywania dzięki handlowi międzynarodowemu (Heckscher, 1919; Ohlin, 1933). W przypadku personelu medycznego na handel międzynarodowy mają wpływ dwa czynniki: migracja zarobkowa oraz turystyka medyczna (komercjalizacja rynku usług na arenie międzynarodowej).

Celem artykułu jest próba opisania wpływu wynagrodzenia i migracji zarobkowej na kondycję i dostęp do opieki zdrowotnej w Polsce. Analiza przypadku dotyczy rynku pracy jednej z grup pracowników ochrony zdrowia - lekarzy. W związku z powyższym postawiono pytania badawcze, czy liczba lekarzy posiadających prawo wykonywania zawodu jest wystarczająca, by zabezpieczyć potrzeby zdrowotne polskiego społeczeństwa, a także czy warunki finansowe oferowane na polskim rynku są korzystne i zaspokajają potrzeby życiowe lekarzy pracujących na terenie kraju. Wnioskowanie zostało przeprowadzone na podstawie danych statystycznych i opracowań Głównego Urzędu Statystycznego (GUS), Eurostatu, Światowej Organizacji Zdrowia (WHO), Organizacji Współpracy Gospodarczej i Rozwoju (OECD), Naczelnej Izby Lekarskiej (NIL), Ministerstwa Zdrowia, a także Centrum Systemów 
Informacyjnych Ochrony Zdrowia (CSIOZ). Ze względu na dostępność danych (stan na 10 maja 2016 r.) badaniami objęto lata 2010-2016.

W celu właściwej oceny rynku ochrony zdrowia GUS wraz z instytucjami państwowymi poddaje analizie przepływy finansowe dotyczące konsumpcji towarów i usług w Narodowym Rachunku Zdrowia (GUS, 2014). Opracowanie za 2013 rok (dane raportowane w 2015 r.) sporządzone zostało na podstawie nowych wyznaczników zgodnych z międzynarodową metodologią, a następnie przekazane w postaci wspólnego kwestionariusza do OECD, Eurostatu i WHO (OECD, Eurostat, WHO, 2011).

Pierwotnie rachunek zdrowia zbudowany był w trzech wymiarach (OECD, Eurostat, WHO, 2011, s. 26-27):

- funkcja systemu opieki zdrowotnej,

- świadczeniodawcy,

- system finansowania.

Obecnie definiowane są dodatkowe wymiary:

a) rodzaje przychodów finansowania systemów zdrowia;

b) czynniki świadczenia opieki zdrowotnej;

c) beneficjenci (w podziale na płeć, wiek, charakterystykę społeczno-ekonomiczną, choroby);

d) kadry w ochronie zdrowia;

e) klasyfikacja towarów i usług opieki zdrowotnej.

Powyższy układ umożliwia spojrzenie na rynek zdrowia w sposób globalny i kompleksowy. Dzięki tym zabiegom możliwe jest uzyskiwanie jednorodnych danych celem dokonywania działań lub przygotowywania strategii na skalę globalną (WHO, 2014, 2016b). Potwierdzeniem tego jest powołanie w 2016 roku Komisji Zdrowia na rzecz zatrudnienia i wzrostu gospodarczego (WHO, 2016a). Jednym z zadań Komisji jest utworzenie do 2030 roku blisko 40 mln nowych miejsc pracy w sektorze zdrowia - głównie w krajach o średnich i wysokich dochodach. Niestety przy obecnym finansowaniu sektora ochrony zdrowia (Polska - 6,4\% PKB przy średniej OECD 8,8\% PKB; rys. 1) założony plan może zostać niezrealizowany. 
Rysunek 1. Poziom publicznych wydatków mierzonych w PKB przeznaczonych na ochronę zdrowia w krajach OECD w 2013 roku

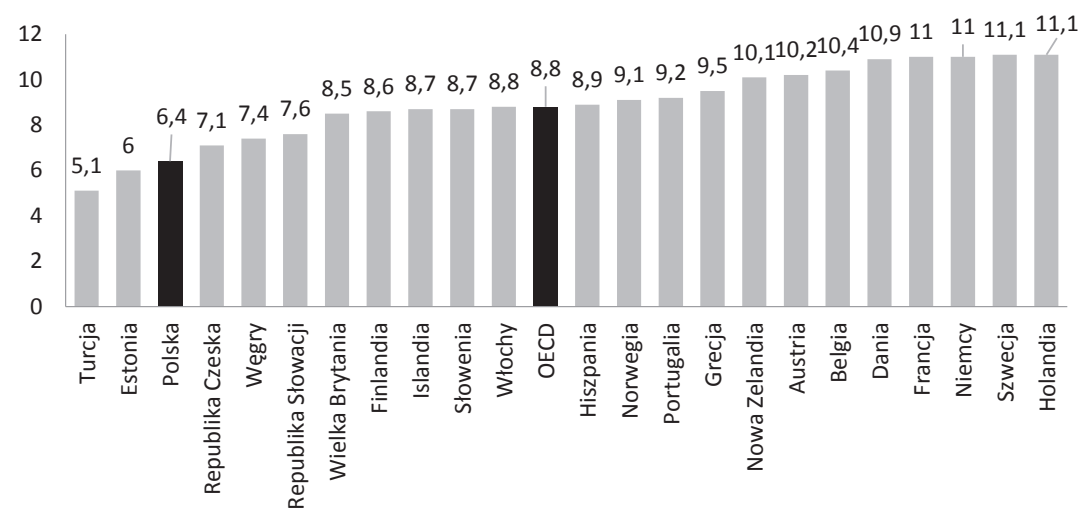

Źródło: opracowanie własne na podstawie: OECD (2016a).

\section{Rynek pracy w ochronie zdrowia na przykładzie wybranej kadry medycznej}

Rosnące potrzeby zdrowotne, czynniki makroekonomiczne, starzenie się społeczeństwa, globalizacja wywierają wpływ na rozwój technologii i usług zdrowotnych oraz ich poszukiwanie poza granicami kraju. Niewłaściwa alokacja zasobów kadrowych oraz kapitału intelektualnego, a także brak prawidłowo funkcjonującego systemu ochrony zdrowia wpływa na jakość usług, ich dostępność i na zdrowie społeczeństwa (Wyszkowska, Hnatyszyn-Dzikowska, 2010). Niezmiennie najważniejszym elementem w ochronie zdrowia są jej pracownicy, a główny jej trzon stanowi kadra medyczna (OECD, 2016, 2015; Kludacz, 2015; Aluttis, Bishaw, Frank, 2014; Golinowska, 2008; Clark, Stewart, Clark, 2006).

Według danych GUS (2015) w Polsce zatrudnionych jest ponad 141 tys. lekarzy, z czego 87,7 tys. pracuje bezpośrednio z pacjentami (w 2014 r. wzrost o 2,78\%). W krajach OECD-34 liczba lekarzy przypadających na 1000 mieszkańców wynosi 3,3 (rys. 2). Dla porównania w Polsce wynik jest znacznie poniżej średniej i kształtuje się na poziomie 2,2 (OECD, 2016). Jest to jeden z najniższych wskaźników w krajach Unii Europejskiej. 
Rysunek 2. Liczba lekarzy praktykujących na 1000 mieszkańców w krajach OECD - dane porównawcze za lata 2000 i 2013

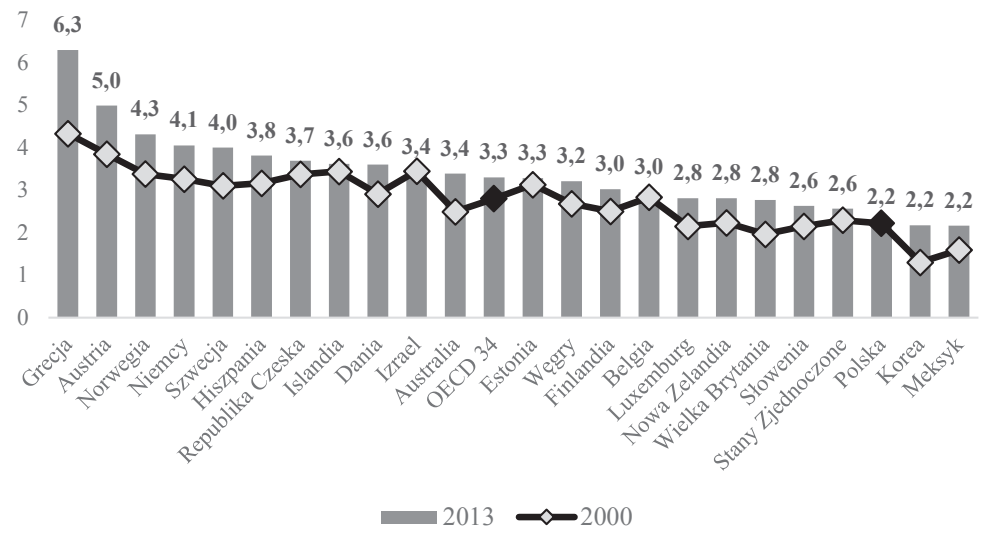

Źródło: opracowanie własne na podstawie: OECD (2016a).

Symboliczne zmiany w liczby lekarzy pracujących bezpośrednio z pacjentami na 10 tys. ludności wynikają z raportu (DBW, 2016), gdzie odnotowano 2,6\% wzrostu w latach 2013-2014 (rys. 3).

Rysunek 3. Lekarze pracujący bezpośrednio z pacjentem na 10 tys. ludności

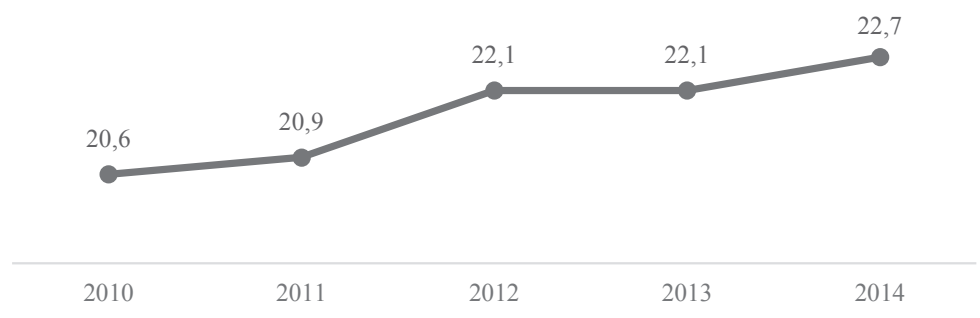

Źródło: opracowanie własne na podstawie: DBW (2016).

Na podstawie danych zawartych w raporcie należy wnioskować, iż liczba lekarzy w Polsce posiadających prawo wykonywania zawodu lekarza z roku na rok przyrasta. W 2014 roku odnotowano wzrost o 1,27\%. Wzrost ten wynika z różnicy między liczbą osób, które zdobyły uprawnienia wykonywania zawodu, a liczbą osób, które odeszły z zawodu. Jednak podejście holistyczne nie wskazuje clou pro- 
blemu, jakim jest niski wskaźnik liczby lekarzy specjalistów. W krótkim horyzoncie w Polsce może wystąpić deficyt lekarzy o specjalności onkologia (spadek o 4,43\%), otolaryngologia (spadek o 6,15\%), neurologia (spadek o 11,28\%), medycyna pracy (spadek o 23,57\%) czy też psychiatria (spadek o 6,31\%) - szczegółowe dane zawarte zostały w tabeli 1 (DBW, 2016).

Tabela 1. Liczba lekarzy posiadających prawo wykonywania zawodu

\begin{tabular}{|c|c|c|c|c|c|c|c|c|c|}
\hline Dane ogólem & 2010 & 2011 & 2012 & 2013 & 2014 & $\begin{array}{c}2011 \text { vs } \\
2010\end{array}$ & $\begin{array}{c}2012 \text { vs } \\
2011\end{array}$ & $\begin{array}{c}2013 \text { vs } \\
2012\end{array}$ & $\begin{array}{c}2014 \text { vs } \\
2013\end{array}$ \\
\hline 1 & 2 & 3 & 4 & 5 & 6 & 7 & 8 & 9 & 10 \\
\hline $\begin{array}{l}\text { Lekarze posiadający } \\
\text { prawo wykonywania } \\
\text { zawodu medycznego }\end{array}$ & 134292 & 136208 & 137109 & 139595 & 141390 & $1,41 \%$ & $0,66 \%$ & $1,78 \%$ & $1,27 \%$ \\
\hline $\begin{array}{l}\text { Lekarze pracujący } \\
\text { bezpośrednio z pa- } \\
\text { cjentem }\end{array}$ & 79337 & 80358 & 85025 & 85246 & 87687 & $1,27 \%$ & $5,49 \%$ & $0,26 \%$ & $2,78 \%$ \\
\hline $\begin{array}{l}\text { Lekarze pracujący } \\
\text { bezpośrednio z pa- } \\
\text { cjentem na } 10 \text { tys. lud- } \\
\text { ności }\end{array}$ & 20,6 & 20,9 & 22,1 & 22,1 & 22,7 & $1,44 \%$ & $5,43 \%$ & $0,00 \%$ & $2,64 \%$ \\
\hline $\begin{array}{l}\text { Lekarze specjaliści; } \\
\text { Ogółem }\end{array}$ & 52715 & 54230 & 58408 & 57847 & 59542 & $2,79 \%$ & $7,15 \%$ & $-0,97 \%$ & $2,85 \%$ \\
\hline $\begin{array}{l}\text { Lekarze specjaliści - } \\
\text { dane szczególowe }\end{array}$ & 2010 & 2011 & 2012 & 2013 & 2014 & $\begin{array}{c}2011 \text { vs } \\
2010\end{array}$ & $\begin{array}{c}2012 \text { vs } \\
2011\end{array}$ & $\begin{array}{c}2013 \text { vs } \\
2012\end{array}$ & $\begin{array}{c}2014 \text { vs } \\
2013\end{array}$ \\
\hline $\begin{array}{l}\text { Anestezjologia i inten- } \\
\text { sywna terapia }\end{array}$ & 2989 & 3044 & 3414 & 3550 & 3718 & $1,81 \%$ & $10,84 \%$ & $3,83 \%$ & $4,52 \%$ \\
\hline Chirurgia & 7401 & 7556 & 8407 & 8203 & 8473 & $2,05 \%$ & $10,12 \%$ & $-2,49 \%$ & $3,19 \%$ \\
\hline Choroby płuc & 1271 & 1295 & 1384 & 1349 & 1365 & $1,85 \%$ & $6,43 \%$ & $-2,59 \%$ & $1,17 \%$ \\
\hline Choroby wewnętrzne & 7031 & 7145 & 7477 & 7183 & 6977 & $1,60 \%$ & $4,44 \%$ & $-4,09 \%$ & $-2,95 \%$ \\
\hline $\begin{array}{l}\text { Dermatologia i wene- } \\
\text { rologia }\end{array}$ & 881 & 891 & 948 & 916 & 898 & $1,12 \%$ & $6,01 \%$ & $-3,49 \%$ & $-2,00 \%$ \\
\hline
\end{tabular}




\begin{tabular}{|l|c|c|c|c|c|c|c|c|c|}
\hline \multicolumn{1}{|c|}{1} & 2 & 3 & 4 & 5 & 6 & 7 & 8 & 9 & 10 \\
\hline Kardiologia & 1723 & 1794 & 2030 & 2132 & 2418 & $3,96 \%$ & $\mathbf{1 1 , 6 3 \%}$ & $4,78 \%$ & $\mathbf{1 1 , 8 3 \%}$ \\
\hline Medycyna rodzinna & 5984 & 6201 & 6509 & 6421 & 6675 & $3,50 \%$ & $4,73 \%$ & $\mathbf{- 1 , 3 7 \%}$ & $3,81 \%$ \\
\hline Medycyna pracy & 818 & 826 & 797 & 776 & 628 & $0,97 \%$ & $\mathbf{- 3 , 6 4 \%}$ & $\mathbf{- 2 , 7 1 \%}$ & $\mathbf{- 2 3 , 5 7 \%}$ \\
\hline Neurologia & 2072 & 2211 & 2396 & 2328 & 2092 & $6,29 \%$ & $7,72 \%$ & $\mathbf{- 2 , 9 2} \%$ & $\mathbf{- 1 1 , 2 8 \%}$ \\
\hline Okulistyka & 1753 & 1799 & 1956 & 1900 & 2012 & $2,56 \%$ & $8,03 \%$ & $\mathbf{- 2 , 9 5 \%}$ & $5,57 \%$ \\
\hline Onkologia & 341 & 388 & 472 & 519 & 497 & $\mathbf{1 2 , 1 1 \%}$ & $\mathbf{1 7 , 8 0 \%}$ & $\mathbf{9 , 0 6 \%}$ & $\mathbf{- 4 , 4 3 \%}$ \\
\hline Otolaryngologia & 1252 & 1268 & 1328 & 1312 & 1236 & $1,26 \%$ & $4,52 \%$ & $\mathbf{- 1 , 2 2 \%}$ & $\mathbf{- 6 , 1 5 \%}$ \\
\hline Pediatria & 3216 & 3224 & 3228 & 3236 & 3321 & $0,25 \%$ & $0,12 \%$ & $0,25 \%$ & $\mathbf{2 , 5 6 \%}$ \\
\hline $\begin{array}{l}\text { Położnictwo i gine- } \\
\text { kologia }\end{array}$ & 3872 & 3869 & 3936 & 3814 & 3841 & $-\mathbf{0 , 0 8} \%$ & $1,70 \%$ & $\mathbf{- 3 , 2 0} \%$ & $0,70 \%$ \\
\hline Psychiatria & 2002 & 2234 & 2313 & 2408 & 2265 & $\mathbf{1 0 , 3 8 \%}$ & $3,42 \%$ & $3,95 \%$ & $\mathbf{- 6 , 3 1 \%}$ \\
\hline Radiodiagnostyki & 1950 & 1979 & 2268 & 2292 & 2259 & $1,47 \%$ & $\mathbf{1 2 , 7 4 \%}$ & $\mathbf{1 , 0 5 \%}$ & $\mathbf{- 1 , 4 6 \%}$ \\
\hline
\end{tabular}

Źródło: DBW (2016).

W tym miejscu warto dodać, iż średni wiek lekarza to 49,5 roku, zaś lekarza posiadającego specjalizację - 54,5 roku. Liczba lekarzy w przedziałach wiekowych 31-40 i 61-70 lat jest znacznie mniejsza niż lekarzy w przedziale wiekowym 41-60 lat, co oznacza, że w niedługiej perspektywie grozi Polsce luka pokoleniowa wśród kadry lekarskiej. Według danych NIL liczba specjalizacji zmniejszy się o 3\% w ciągu 10 lat, a w ciągu 20 lat o 9\% (Krajewski, 2015, s. 8; Bodnar, 2016).

Dostępność kadry medycznej możemy rozpatrywać zarówno w ujęciu globalnym, jak i lokalnym. W poszczególnych województwach Polski najmniejszą grupę lekarzy pracujących bezpośrednio z pacjentowi możemy zaobserwować w województwie opolskim, lubuskim, świętokrzyskim, podlaskim i warmińsko-mazurskim - poniżej 3 tys. (rys. 4). Najwięcej lekarzy pracuje w województwie mazowieckim - ponad 14 tys. (DBW, 2016). 
Rysunek 4. Lekarze pracujący bezpośrednio z pacjentem
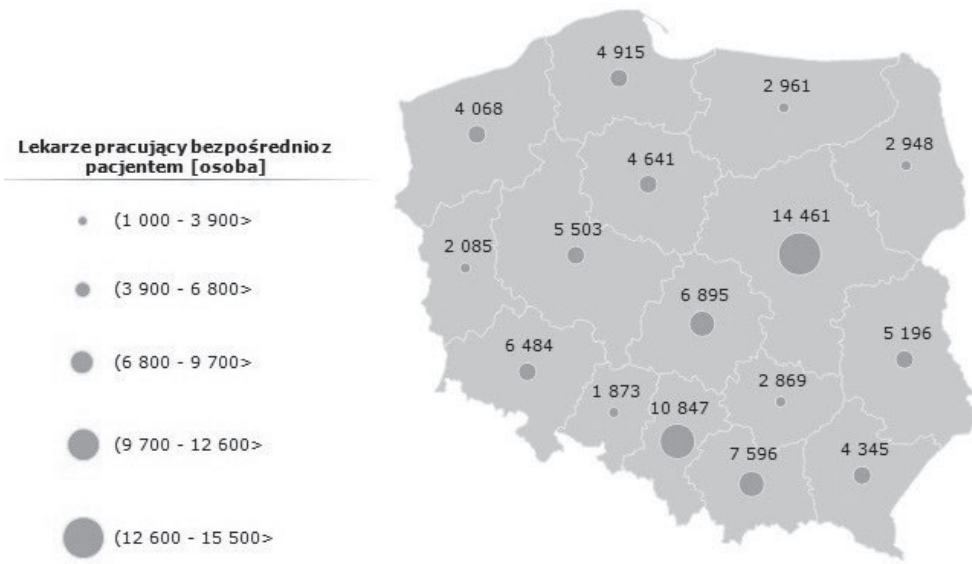

Źródło: DBW (2016).

Z przeprowadzonym badań wynika, że w województwie wielkopolskim możemy zaobserwować najmniejszą liczbę lekarzy pracujących z pacjentem na 10 tys. ludności $(15,8)$, największą zaś w województwie łódzkim $(27,5)$, mazowieckim $(27,1)$ i zachodniopomorskim $(23,7)$ - rysunek 5 (DBW, 2016).

Rysunek 5. Lekarze pracujący bezpośrednio z pacjentem na 10 tys. ludności
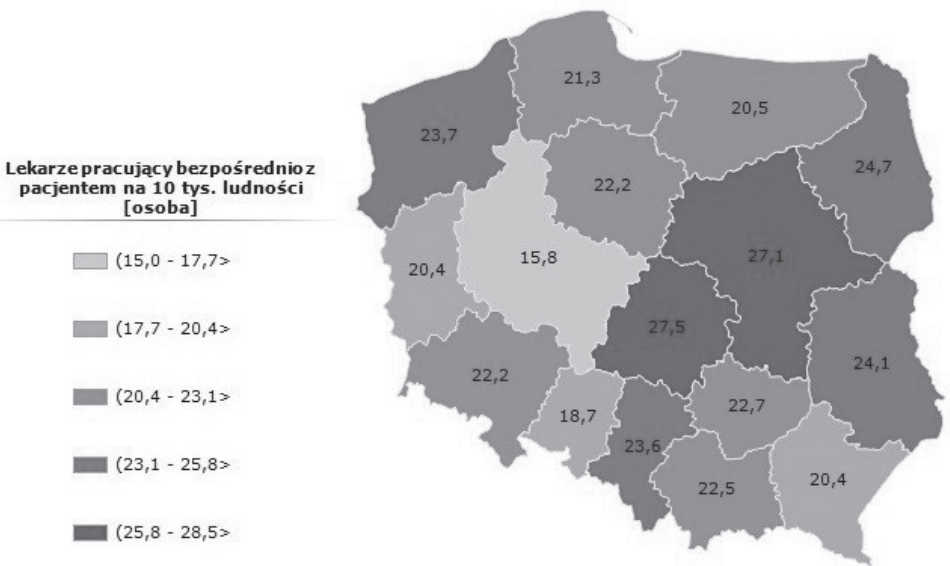

Źródło: DBW (2016). 
Z zebranego materiału wynika, że w Polsce liczba lekarzy posiadających prawo wykonywania zawodu jest niewystarczająca, by zabezpieczyć potrzeby zdrowotne. Alokacja zasobów kadrowych pracujących bezpośrednio z pacjentami różni się pomiędzy województwami i liczba ta waha się od 15,8 do ponad 27 lekarzy na 10 tys. ludności. Dodatkowo struktura wieku lekarzy uprawnionych do wykonywania zawodu jest alarmująca, ponieważ utrzymuje się tendencja wzrostowa osób w przedziale wiekowym powyżej 51 roku życia. Napływ nowej kadry, która mogłaby w sposób naturalny zrównoważyć zasób kadry medycznej, jest niewystarczający. Spowodowane jest to czynnikami regulacyjnymi, płacowymi, a także trudnościami dalszego rozwoju (Ministerstwo Zdrowia, 2016).

\section{Wynagrodzenia lekarzy}

W Polsce według danych GUS przeciętne miesięczne wynagrodzenie ogółem brutto w październiku 2014 roku wyniosło 4 107,72 zł. Lekarze ze stażem powyżej dwóch lat zarabiają więcej niż przeciętne średnie wynagrodzenie. Pogłębia się różnica między najniższym wynagrodzeniem a wynagrodzeniem za staż powyżej 10 lat - w 2014 roku wyniosła 144\% (rys. 6).

Rysunek 6. Przeciętne wynagrodzenie lekarzy według stażu pracy [wartość brutto zł]

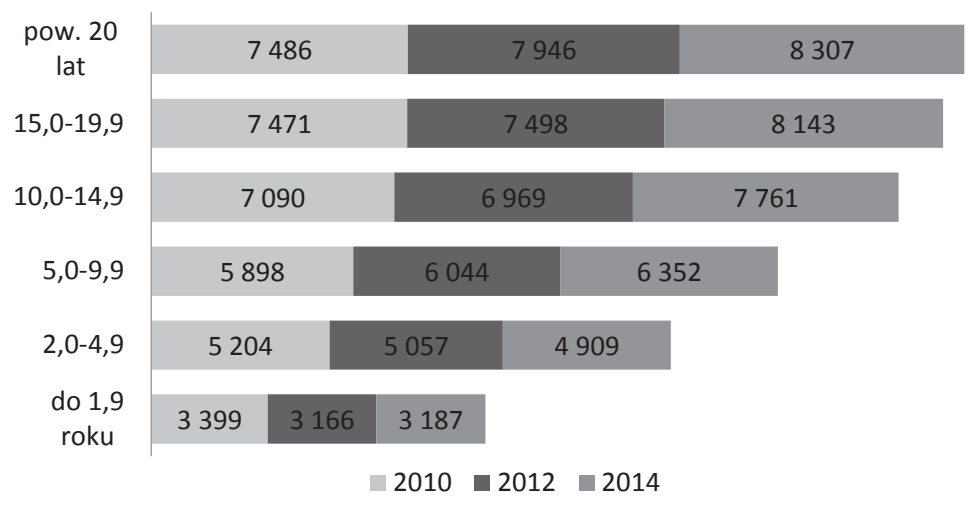

Źródło: opracowanie własne na podstawie: GUS (2016). 
Najlepiej zarabiającą grupą lekarzy są osoby w wieku 45-54 lat i powyżej 65 lat (zob. rys. 7). Najmniej zarabiają młodzi lekarze, którzy dopiero zbierają doświadczenia, by w późniejszym okresie mogło ono zaprocentować wyższą gażą. Przy tej okazji należy dodać, iż wynagrodzenia osób odbywających specjalizację w ramach rezydentury są ściśle określone i od 2012 roku nie uległy zmianie. W dwóch pierwszych latach rezydentury wartość zasadniczego miesięcznego wynagrodzenia wynosi 3602 zł, a po dwóch latach - 3890 zł.

Rysunek 7. Przeciętne wynagrodzenie lekarzy według wieku [wartość brutto zł]

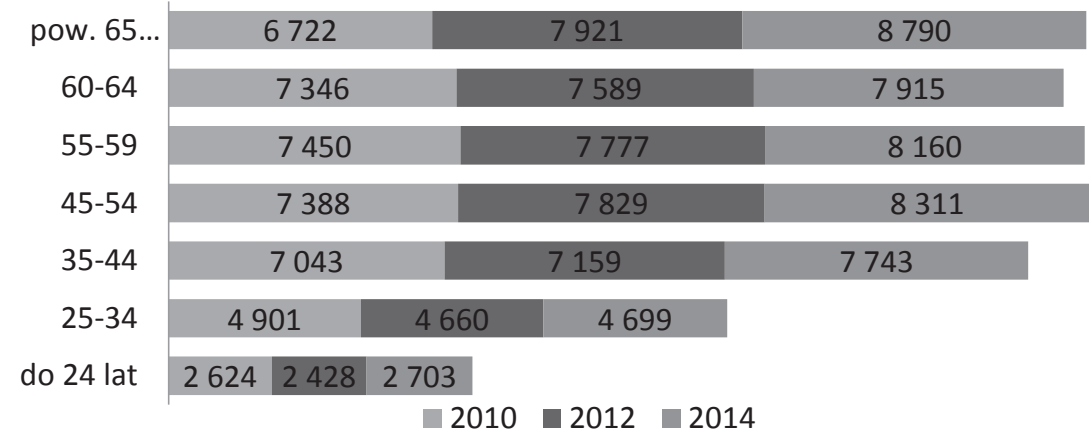

Źródło: opracowanie własne na podstawie: GUS (2016).

Pracując w sektorze prywatnym lekarz jest w stanie zwiększyć swoje wynagrodzenie o ponad 10\%. Szczegóły dostępne są w raporcie GUS z 2014 roku (rys. 8). Należy wziąć pod uwagę, iż różnica ta może wynikać z liczby przepracowanych godzin w poszczególnych sektorach. Wynagrodzenia pracowników podmiotów leczniczych działających $\mathrm{w}$ formie jednostki budżetowej są ściśle określone w (Rozporządzenie, 2016), a doświadczeni lekarze mają możliwość pracy u kilku pracodawców. 
Rysunek 8. Przeciętne wynagrodzenie lekarzy według sektorów własności [wartość brutto zł]

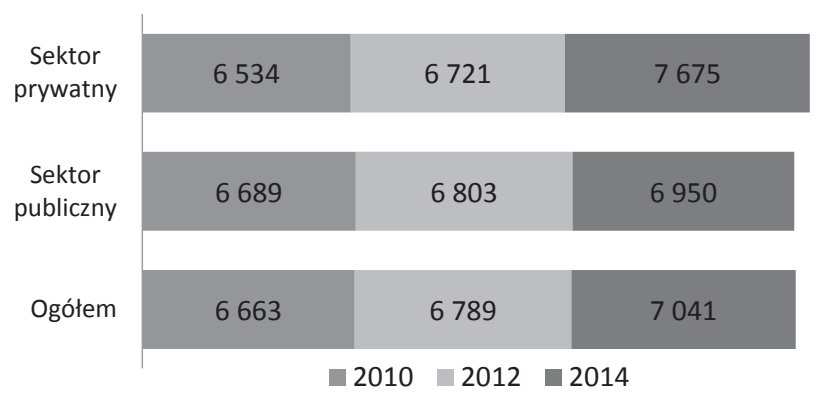

Źródło: opracowanie własne na podstawie: GUS (2016).

Lekarze zdobywający doświadczenie oraz rezydenci mają ograniczone możliwości zarobkowania, a co się z tym wiąże - wysokość ich wynagrodzeń jest relatywnie niska w stosunku do nakładów pracy. Brak możliwości rozwojowych, powolny rozwój technologiczny i słaba kondycja finansowa wpływa na ich decyzję o migracji. Czynniki te powodują, iż kryzys związany z dostępem do świadczeń medycznych w Polsce w najbliższych latach pogłębi się.

\section{Migracja zarobkowa wybranej kadry medycznej}

Polska jako jeden z niewielu krajów Unii Europejskiej posiada w swoich zasobach kadrowych nieliczną grupę lekarzy cudzoziemców lub lekarzy wyszkolonych poza granicami Polski (OECD, 2015, s. 89). Według danych OECD za 2012 rok lekarzy z kwalifikacjami zdobytymi poza Polską pracuje zaledwie 2203, co stanowi $1,8 \%$ w stosunku do ogółu wszystkich pracujących lekarzy w Polsce. W Republice Czeskiej udział lekarzy cudzoziemców lub z kwalifikacjami zdobytymi poza krajem jest na poziomie 5,1\%, w Niemczech i we Francji powyżej 8\%, w Norwegii powyżej $35 \%$. przy średniej OECD na poziomie 17,3\% (rys. 9). 
Rysunek 9. Udział procentowy lekarzy cudzoziemców na danym rynku - dane OECD za 2012 rok

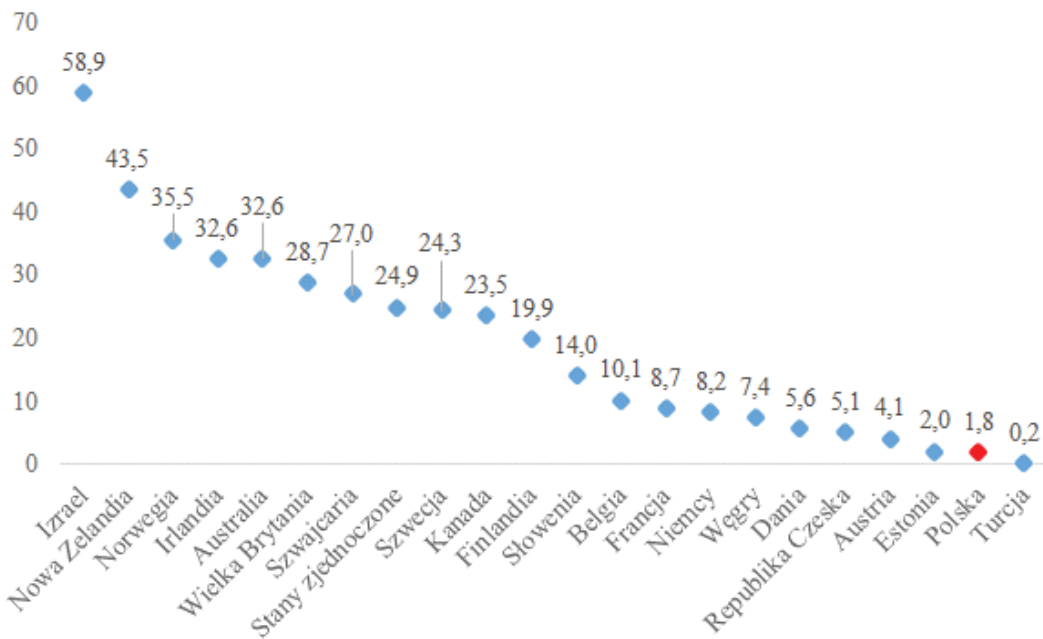

Źródło: opracowanie własne na podstawie: OECD Stat. (2016c).

W latach 2006-2012 średniorocznie przybyło do Polski 67 wyszkolonych lekarzy. Taki rezultat jest wynikiem przeszkód prawnych stojących po stronie systemu, wysokości wynagrodzeń, warunków pracy i wysokich barier w zdobywaniu specjalizacji, a nie w kontekście wiedzy i zdobytego doświadczenia (WHO, 2014, s. 25). Nie ma prowadzonych wielu badań na temat lekarzy imigrujących do Polski - głównie prowadzone są analizy przyczynowo-skutkowe w obszarze emigrujących z Polski pracowników ochrony zdrowia (Andrejuk, 2015; Kautsch, 2013).

Niewątpliwie jednym z czynników, który przyczynił się do większej dynamiki fali migracji lekarzy, było przystąpienie Polski do Unii Europejskiej. Kolejny istotny element stanowią prawa wspólnotowe oraz automatycznie przyznawane kwalifikacje zawodowych w ramach wspólnego rynku. Impulsem do zmiany były warunki pracy, wysokość wynagrodzenia i możliwość podnoszenia swoich kwalifikacji, czyli wszystko to, co utrudnia lekarzom pracę w Polsce. Według NIL (2016) do 3 marca 2016 roku lekarzom zostało wydanych 10371 zaświadczeń niezbędnych do pojęcia pracy poza granicami kraju, co stanowi 7,9\% ogólnej liczby lekarzy. Wydane zaświadczenie nie 
oznacza, iż wszyscy lekarze podejmą pracę za granicą, jednak już częściowy ich odpływ wpłynie negatywnie na dostęp do opieki zdrowotnej w Polsce. Mniejsza liczba lekarzy anestezjologów, chirurgów, radiologów wydłuży czas oczekiwania na przeprowadzenie zabiegów i pogorszy stan zdrowia polskiego społeczeństwa. Należy pamiętać o tym, że wraz z migracją kadry medycznej zabraknie wiedzy, umiejętności i możliwości zabezpieczenia potrzeb zdrowotnych.

Tabela 2. Liczba zaświadczeń wydanych lekarzom ubiegających się o uznanie kwalifikacji w innych krajach Unii Europejskiej

\begin{tabular}{|c|c|c|c|}
\hline Dane szczególowe - specj alizacja & $\begin{array}{c}\text { Liczba lekarzy } \\
\text { wykonujących } \\
\text { zawód }\end{array}$ & $\begin{array}{c}\text { Liczba lekarzy, } \\
\text { którym wydano } \\
\text { zaświadczenia }\end{array}$ & $\begin{array}{c}\text { Wskaźnik } \\
{[\mathbf{\%}]}\end{array}$ \\
\hline Chirurgia klatki piersiowej & 259 & 46 & $\mathbf{1 7 , 7 6}$ \\
\hline Anestezjologia i intensywna terapia & 5230 & 892 & $\mathbf{1 7 , 0 6}$ \\
\hline Chirurgia plastyczna & 201 & 32 & 15,92 \\
\hline Patomorfologia & 563 & 73 & $\mathbf{1 2 , 9 7}$ \\
\hline Radiologia i diagnostyka obrazowa & 2756 & 293 & $\mathbf{1 0 , 6 3}$ \\
\hline Medycyna ratunkowa & 920 & 90 & 9,78 \\
\hline Ortopedia i traumatologia narządu ruchu & 3250 & 592 & 9,75 \\
\hline Chirurgia ogólna & 6104 & 50 & 9,70 \\
\hline Neurochirurgia & 529 & 107 & 9,45 \\
\hline Urologia & 1259 & 475 & 8,50 \\
\hline Położnictwo i ginekologia & 6235 & & 7,62 \\
\hline
\end{tabular}

Źródło: NIL (2016).

\section{Podsumowanie}

Według badań OECD (2016) przeprowadzonych w 31 krajach w 2012 roku w celu osiągnięcia lepszej alokacji zasobów kadrowych należy przeprowadzić kluczowe zmiany, czyli właściwie rozdystrybuować siły - zgodnie z potencjałem 
regionu, wyrównać niedobory określonych specjalizacji na danych obszarach, zwiększyć lub co najmniej utrzymać udział PKB w obszarze zdrowia w celu zaspokojenia potrzeb na usługi, utrzymać co najmniej ten sam poziom lekarzy. Migracja i wysokość zarobków przyczyniły się do uszczuplenia zasobów kadrowych na rynku w Polsce. Biorąc pod uwagę niski napływ lekarzy do Polski z innych krajów, możemy się spodziewać względnie niższej liczby kadry medycznej w przyszłości, co przy obecnie i tak najniższym w krajach Unii Europejskiej poziomie lekarzy przypadających na 1000 mieszkańców (wskaźnik na poziomie 2,2) może stanowić w najbliższych latach duże wyzwanie dla rynku pracy w sektorze ochrony zdrowia. Warto dodać, że w Polsce wskaźnik ten kształtuje się na tym samym poziomie od 2000 roku.

Wynagrodzenia i migracja zarobkowa mają wpływ na kondycję i dostęp do świadczeń opieki zdrowotnej w Polsce. Bez strategicznego działania w obszarach wymagających zmian, to jest finansowania - właściwej alokacji środków, edukacji, większej liczby miejsc dla rezydentów, liczba lekarzy posiadających prawo wykonywania zawodu nie jest wystarczająca, by zabezpieczyć potrzeby zdrowotne polskiego społeczeństwa. Warunki finansowe oferowane na polskim rynku nie zaspokajają potrzeb życiowych lekarzy pracujących na terenie kraju, zwłaszcza lekarzy młodych i rezydentów.

Należy również zwrócić uwagę na fakt, iż wzrost stawki płacy wywołuje jednocześnie dwa przeciwstawne efekty: substytucyjny i dochodowy (rys. 10). Efekt substytucyjny polega na tym, że wyższa stawka płacy zachęca ludzi do tego, by pracowali więcej (wyższa wycena czasu, wyższa konsumpcja). Jednak po okresie wzmożonej aktywności każdy człowiek dochodzi do krytycznego momentu, co przedstawia punkt $T$ na rysunku 10 . W momencie osiągnięcia punku $T$ krzywa zaczyna się odchylać do tyłu, ponieważ bogatsi ludzie bardziej cenią własny czas wolny niż pracę. Efekt dochodowy powoduje wzrost bogactwa społeczeństwa poprzez wzrost stawki płacy. 
Rysunek 10. Zagięta wstecz krzywa podaży pracy

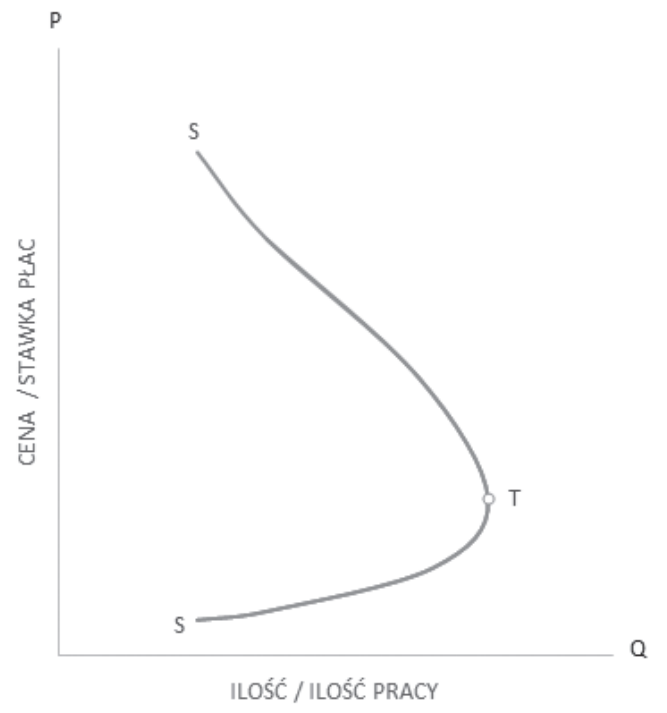

Źródło: opracowanie własne na podstawie: Samuelson, Nordhaus (2014), s. 161.

Badania aplikacyjne wykazują, że efekt substytucyjny jest silniejszy od dochodowego w krótszych okresach dla całego rynku. Jednak czy tak będzie z lekarzami pracownikami ochrony zdrowia w Polsce? To pytanie jest doskonałym początkiem do przeprowadzenia badań i stawiania kolejnych hipotez w tym kierunku.

\section{Literatura}

Aluttis, C., Bishaw, T., Frank, M. (2014). The Workforce for Health in a Global Shortages and International Migration. Global Health Action, 7. Pobrane z: http://www.globalhealthaction.net/index.php/gha/article/view/23611 (4.05.2016).

Andrejuk, K. (2015). Migracja lekarzy czy migracja, aby zostać lekarzem? Kraje pochodzenia i trajektorie kariery cudzoziemskiej kadry medycznej w Polsce. Studia Migracyjne Przegląd Polonijny, 1 (155), 133-160. Pobrane z: http://cejsh.icm.edu.pl/cejsh/element/ bwmeta1.element.desklight-f20e00e1-9776-472a-a2cd-e06f0be7f752 (3.05.2016).

Bodnar, A. (2016). Zatrudnianie lekarzy obcokrajowców spoza UE. Pobrane z: https://www. rpo.gov.pl/sites/default/files/Do_MZ_ws_trudnosci_z_zatrudnianiem_w_Polsce_lekarzy_obcokrajowcow_spoza_Unii_Europejskiej.pdf (10.05.2016). 
Clark, P., Stewart, J., Clark, D. (2006). The Globalization of the Labour Market for Health-Care Professionals. International Labour Review, 145/1-2 AB, 37. DOI:10.1111/j.1564-913X.2006.tb00009.x (4.05.2016).

DBW (2016). Zdrowie i Ochrona Zdrowia. Kadra medyczna. Pobrane z: http://swaid.stat. gov.pl/SitePages/StronaGlownaDBW.aspx (10.05.2016).

Golinowska, S. (2008). Rynek pracy w sektorze zdrowotnym - zaniedbany obszar zarządzania. Polityka Społeczna, 7, 1-5. Pobrane z: http://www.ipiss.com.pl/wp-content/ uploads/downloads/2012/10/ps_7_2008_s_golinowska.pdf (10.05.2016).

GUS (2014). Narodowy Rachunek Zdrowia za 2012 rok. Pobrane z: http://stat.gov.pl/obszary-tematyczne/zdrowie/zdrowie/narodowy-rachunek-zdrowia-za-2012-rok,4,5.htmlf (9.05.2016).

GUS (2015). Zdrowie i ochrona zdrowia w 2014 r. Pobrane z: http://stat.gov.pl/obszary-tematyczne/zdrowie/zdrowie/zdrowie-i-ochrona-zdrowia-w-2014-r-,1,5.html (8.05.2016).

GUS (2016). Struktura wynagrodzeń wedlug zawodów w październiku 2014 r. Pobrane z: http://stat.gov.pl/obszary-tematyczne/rynek-pracy/pracujacy-zatrudnieni-wynagrodzenia-koszty-pracy/struktura-wynagrodzen-wedlug-zawodow-w-pazdzierniku2014-r-,4,7.html (8.05.2016).

Heckscher, E. (1919). The Effect of Foreign Trade on the Distribution of Income. Ekonomisk Tidskrift, 21, 497-512. [Przedrukowane w: Readings in the Theory of International Trade (Homewood, IL, Irwin, 1949), 272-300. Przetłumaczone w: Flam, H., Flanders, M.J. (red.). (1991). Heckscher-Ohlin Trade Theory, MIT Press: 43-69, Cambridge MA] Kautsch, M. (2013). Migracje personelu medycznego i ich skutki dla funkcjonowania systemu ochrony zdrowia w Polsce. Zdrowie Publiczne $i$ Zarzadzanie, 11 (2): 169-179. Pobrane z: www.ejournals.eu/Zdrowie-Publiczne-i-Zarzadzanie (10.05.2016). DOI:10.4467/20842627OZ.14.015.1625.

Kludacz, M. (2015). Problem dostępności zasobów ludzkich w polskim systemie ochrony zdrowia na tle innych krajów Organizacji Współpracy Gospodarczej i Rozwoju. Ekonomia i Zarzadzanie, 1 (7), 9-31. Pobrane z: http://yadda.icm.edu.pl/yadda/element/ bwmeta1.element.baztech-dbce739e-fc1a-4cd8-9d2a-57ee568a3ce0/c/kludacz_problem_dostepnosci_1_2015.pdf.pdf(3.05.2016). DOI:10.12846/j.em.2015.01.01.

Krajewski, R. (2015). Lekarze specjaliści i lekarze dentyści specjaliści - sytuacja demograficzna. Pobrane z: http://www.nil.org.pl/_data/assets/pdf_file/0003/101199/Raport2015-lekarze-specjalisci-i-lekarze-dentysci-specjalisci.pdf (10.05.2016).

Ministerstwo Zdrowia (2016). Komunikat ws. rezydentur przyznanych na postepowanie wiosenne z danymi liczbowymi (marzec 2016). Pobrane z: http://www.mz.gov.pl/system-ochrony-zdrowia/kadra-medyczna-i-ksztalcenie/lekarze-i-lekarze-dentysci/ko- 
munikaty-dla-lekarzy-i-lekarzy-dentystow/komunikat-ws-rezydentur-przyznanych-na -postepowanie-wiosenne-z-danymi-liczbowymi-marzec-2016/ (8.05.2016).

Naczelna Izba Lekarska (2016). Liczba zaświadczeń wydanych lekarzom ubiegajacym się o uznanie kwalifikacji w innych krajach UE. Pobrane z: http://www.nil.org.pl/_data/ assets/pdf_file/0017/105452/Zestawienie-nr-06a.pdf (7.05.2016).

OECD (2015). Health at a Glance 2015: OECD Indicators. Pobrane z: http://dx.doi. org/10.1787/health_glance-2015-en; http://www.keepeek.com/Digital-Asset-Management/oecd/social-issues-migration-health/health-at-a-glance-2015_health_glance2015-en\#page3 (8.05.2016).

OECD (2016). Health Workforce Policies in OECD Countries: Right Jobs, Right Skills, Right Places. Pobrane z: www.keepeek.com/Digital-Asset-Management/oecd/social-issues -migration-health/health-workforce-policies-in-oecd-countries_9789264239517-en\#page50 (8.05.2016).

OECD, Eurostat, WHO (2011). A System of Health Accounts 2011. European Union. Pobrane Z: http://www.who.int/health-accounts/methodology/sha2011.pdf (7.05.2016).

OECD Stat. (2016a). Health Expenditure and Financing. Pobrane z: : http://stats.oecd.org (10.05.2016).

OECD Stat. (2016b). Health Care Resources. Pobrane z: http://stats.oecd.org (10.05.2016).

OECD Stat. (2016c). Health Workforce Migration. Pobrane z: http://stats.oecd.org (10.05.2016).

Ohlin, B. (1933). Interregional and International Trade. Cambridge: Harvard University Press.

Rozporządzenie Ministra Zdrowia z 20.12.2012 w sprawie wysokości zasadniczego wynagrodzenia miesięcznego lekarzy i lekarzy dentystów odbywających specjalizacje w ramach rezydentury. Dz.U. 2012, poz. 1498. Pobrane z: http://dziennikustaw.gov.pl/ DU/2012/1498/1 (8.05.2016).

Rozporządzenie Ministra Zdrowia z 3.03.2016 zmieniające rozporządzenie w sprawie warunków wynagradzania za pracę pracowników podmiotów leczniczych działających w formie jednostki budżetowej. Dz.U. 2016, poz. 305. Pobrane z: http://dziennikustaw. gov.pl/DU/2016/305/1 (8.05.2016).

Samuelson, P.A., Nordhaus, W.D. (2014). Ekonomia. Poznań: Rebis.

Suchecka, J. (2010). Ekonomia zdrowia i opieki zdrowotnej. Warszawa: Wolters Kluwer.

WHO (2014). Migration of Health Workers Who Code of Practice and the Global Economic Crisis. Pobrane z: http://www.who.int/hrh/migration/14075_MigrationofHealth_Workers.pdf (8.05.2016). 
WHO (2016a). Commission on Health Employment and Economic Growth. Pobrane z: http://www.who.int/hrh/com-heeg/en/ (8.05.2016).

WHO (2016b). Global Strategy on Human Resources for Health: Workforce 2030. Pobrane z: http://www.who.int/hrh/resources/globstrathrh-2030/en/ (8.05.2016).

Wyszkowska, Z., Hnatyszyn-Dzikowska, A. (2010). Ocena konwergencji sytuacji zdrowotnej w polskich regionach na tle podaży usług zdrowotnych. Nierówności Spoteczne a Wrrost Gospodarczy, 17, 433-442. Pobrane z: http://www.ur.edu.pl/pliki/Zeszyt17/35.pdf (10.05.2016).

\title{
INFLUENCE ON HEALTHCARE EMPLOYMENT IN POLAND OF MIGRATION AND THE INCOME LEVELS OF DOCTORS
}

\begin{abstract}
This article attempts to present the labor market in the healthcare sector with particular emphasis on the impact of income levels and labor migration on its condition. According to the World Health Organization (WHO) migration of medical personnel may lead to unequal access to healthcare, not only within the country but also on a global scale. This case study analyses the labor market of one of the groups of healthcare professionals: doctors.

The material has been prepared on the basis of analyses and reports the Polish Central Statistical Office (GUS), the Organization for Economic Cooperation and Development (OECD), the World Health Organization (WHO), the Polish Chamber of Physicians (NIL), the Polish Ministry of Health.
\end{abstract}

Keywords: Healthcare, labor market, migration, income

JEL codes: H51, I11, I14, I15, J21, J44, J45 